\title{
In-Line Radiolabeling: A Novel Continuous-Flow System for Commercial-Scale Protein Labeling
}

Debra A. Harris ${ }^{1}$, Raimo Pellikka ${ }^{2}$, Olga Gasser ${ }^{2}$, Peter Blaeuenstein ${ }^{2}$, Robert Waibel $^{2}$, P. August Schubiger ${ }^{2,3}$, Steven W. King ${ }^{1}$, and Missag H. Parseghian ${ }^{1}$

${ }^{1}$ Research and Development, Peregrine Pharmaceuticals Inc., Tustin, California; ${ }^{2}$ Center for Radiopharmaceutical Science, Paul Scherrer Institute, Villigen, Switzerland; and ${ }^{3}$ Department of Chemistry and Applied Biosciences, Institute of Pharmaceutical Sciences, Swiss Federal Institute of Technology, Zurich, Switzerland

A key limitation in developing radiotherapeutic proteins is the expense of manufacturing the drug in small batches using traditional reaction vessels. Removing limitations on the quantity of protein labeled at any one time significantly decreases the cost of production, and nowhere is the need for cost-effective radiotherapeutics more acute than in the treatment of cancer. Methods: We describe a novel method that can rapidly radiolabel, theoretically, unlimited amounts of protein, without causing significant damage to binding potency or structural integrity. Our process controls the reaction rate for the isotope and reactants as they simultaneously flow through a reaction tube. Results: We have demonstrated proof of principle by labeling nearly a gram of antibody with $481 \mathrm{GBq}(13 \mathrm{Ci})$ of ${ }^{131}$ I during a single 30-min reaction run. Conclusion: Simple to construct, our system is already used to manufacture a radiolabeled antibody, both in the United States and in India, as part of clinical trials to treat glioblastoma multiforme. Modified, this system may be also applicable for nonradioactive labeling.

Key Words: radiolabeling; protein labeling; nuclear medicine; radiotherapeutic antibodies; glioblastoma multiforme

J Nucl Med 2009; 50:1178-1186

DOI: 10.2967/jnumed.108.056812

\section{W}

ith the establishment of radioactive biologics into the realm of health care $(1,2)$, it has become imperative to devise radiolabeling procedures that can deliver multiple doses to patients in a rapid and cost-effective manner. In fact, it has been more than $60 \mathrm{y}$ since the first protein molecules were labeled (3) and nearly that long since the first radiolabeling of antibodies (4). Both events used ${ }^{131} \mathrm{I}$, a commercially available $\beta$ - and $\gamma$-radiation emitter with an 8.1-d half-life, which is relatively inexpensive. These characteristics have continued to make ${ }^{131} \mathrm{I}$ attractive for clinical applications (5).

Received Aug. 11, 2008; revision accepted Mar. 18, 2009.

For correspondence or reprints contact: Missag H. Parseghian,

Research and Development, Peregrine Pharmaceuticals Inc., 14272

Franklin Ave., Tustin, CA 92780.

E-mail: mparseghian@peregrineinc.com

COPYRIGHT @ 2009 by the Society of Nuclear Medicine, Inc.
Perhaps a downside to its use is the need for patient isolation to prevent unnecessary exposure to care providers and family members (6). Such a significant cost component, offset by improvements in production costs, can help radiotherapeutics gain a wider acceptance.

Cotara (Peregrine Pharmaceuticals, Inc.), the trade name for a mouse-human chimeric monoclonal antibody known as chTNT-1/B, is a ${ }^{131} \mathrm{I}$-radiolabeled version of an antibody that targets the necrotic core of any solid tumor. Cotara is currently in clinical trials for the treatment of brain tumors (7). Unlike other tumors, brain tumors present special challenges for the development of effective therapies, such as the maximum volume of drug that can be administered without causing edema $(\sim 9 \mathrm{~mL})$ or the maximum amount of cations (i.e., sodium and potassium) in the drug product that can be tolerated by a patient. To meet the needs of radiation oncologists, we had to tackle the following series of challenges: Design a radiolabeling procedure that allows for the intratumoral administration of up to $5.55 \mathrm{GBq}(150$ $\mathrm{mCi}$ ) of ${ }^{131} \mathrm{I}$-labeled Cotara to a patient within $5 \mathrm{~d}$ of radiolabeling; given the half-life of ${ }^{131} \mathrm{I}$, this calls for the preparation of a "patient dose" of approximately $8.33 \mathrm{GBq}$ ( $\sim 225 \mathrm{mCi})$ of ${ }^{131} \mathrm{I}$ antibody on the day of manufacture; keep the volume of this $8.33-\mathrm{GBq}(225-\mathrm{mCi})$ final drug product to no more than $9 \mathrm{~mL}$ ( $8 \mathrm{~mL}$ would be preferable); ensure that the binding potency of Cotara and the percentage of intact antibody monomer remain stable, when frozen, for at least $5 \mathrm{~d}$; ensure that the radioactive free iodide content does not increase to levels that are detrimental to the patient when the product is frozen for at least $5 \mathrm{~d}$; keep the ${ }^{131}$ I-labeled antibody stable when thawed at day 5 (it should remain stable at room temperature for up to $24 \mathrm{~h}$ because the drug must be slowly administered to a patient over a period of time [we denote this as day $5+$ $24 \mathrm{~h}$ in this article]); keep the process flexible enough for scale-up for simultaneous production of multiple patient doses during commercialization of the drug product; and finally, bring down the overall production costs for the drug product using the process. 
In the six decades since the first ${ }^{131}$ I labeling of proteins, several chemical strategies have been developed for the conjugation of the isotope. The most common methods use either oxidizing agents, such as chloramine-T (Mallinckrodt), IODO-GEN (Pierce), and IODO-BEADS (Pierce), or bifunctional cross-linking agents, such as the Bolton-Hunter reagent (8). Having been developed for labeling of research materials, each chemistry has its shortcomings when applied to larger pharmaceutical manufacturing scales. IODO-GEN is an $\mathrm{N}$-haloamine derivative that is insoluble in aqueous solution, making it a useful oxidizing agent that can be coated on the surface of reaction vessels. All one does is remove the protein and isotope solution from the vessel to stop the reaction. Unfortunately, one is limited in the amount of protein that is labeled by the size of the reaction vessel. Similarly, IODO-BEADS localize the oxidizing agent on the surface of polystyrene beads; however, with a reported maximum iodination of $500 \mu \mathrm{g}$ of protein per bead, this process is also limited by the amount of beads that can be contained in a reaction vessel (8). The Bolton-Hunter reagent and its derivatives allow for the indirect labeling by conjugation of the isotope to a cross-linking agent first, followed by a second step for the conjugation of the cross-linking agent to the protein. The disadvantages of such a scheme for the largescale manufacture of drugs are the additional steps needed to prepare the radiolabeled cross-linker, remove unincorporated radiolabel, react the radiolabeled cross-linker with the protein, and then remove the unincorporated cross-linker.

Chloramine- $\mathrm{T}$ is one of the most popular oxidizing reagents for radiolabeling antibodies; however, its properties can lead to oxidative damage for some proteins that require relatively long incubation times $(>10 \mathrm{~min})$. Furthermore, those choosing to label radiopharmaceuticals with chloramine- $T$ generally quench the reaction with a reductant, such as sodium metabisulfite, which requires subsequent testing for its removal from the final drug product. Radiolabeling is generally conducted in a container as a "batch"-labeling reaction, thus increasing the chances of radiolysis for the protein due to exposure to a high concentration of radiation within the reaction vessel. Here we discuss proof-of-principle testing of a new labeling system that replaces the reaction vessel with a silicone reaction tube. By running the reaction as the components flow through the tube, only a portion of the reactants is mixed together at any given time; hence, the deleterious effects of concentrated radioactivity and chloramine- $\mathrm{T}$ can be dissipated. We refer to this process as "In-Line" radiolabeling; theoretically, a limitless amount of protein can be labeled by simply adjusting the dimensions of the tubing.

The process uses basic chloramine-T chemistry in the apparatus shown in Figure 1. Three reagent vials containing antibody, chloramine-T, and ${ }^{131} \mathrm{I}$ are kept separate to prevent premature radiolysis and oxidation of the antibody. They are combined through the action of a 3-channel peristaltic pump in which they are propelled individually through the pump and enter a single manifold. Once the
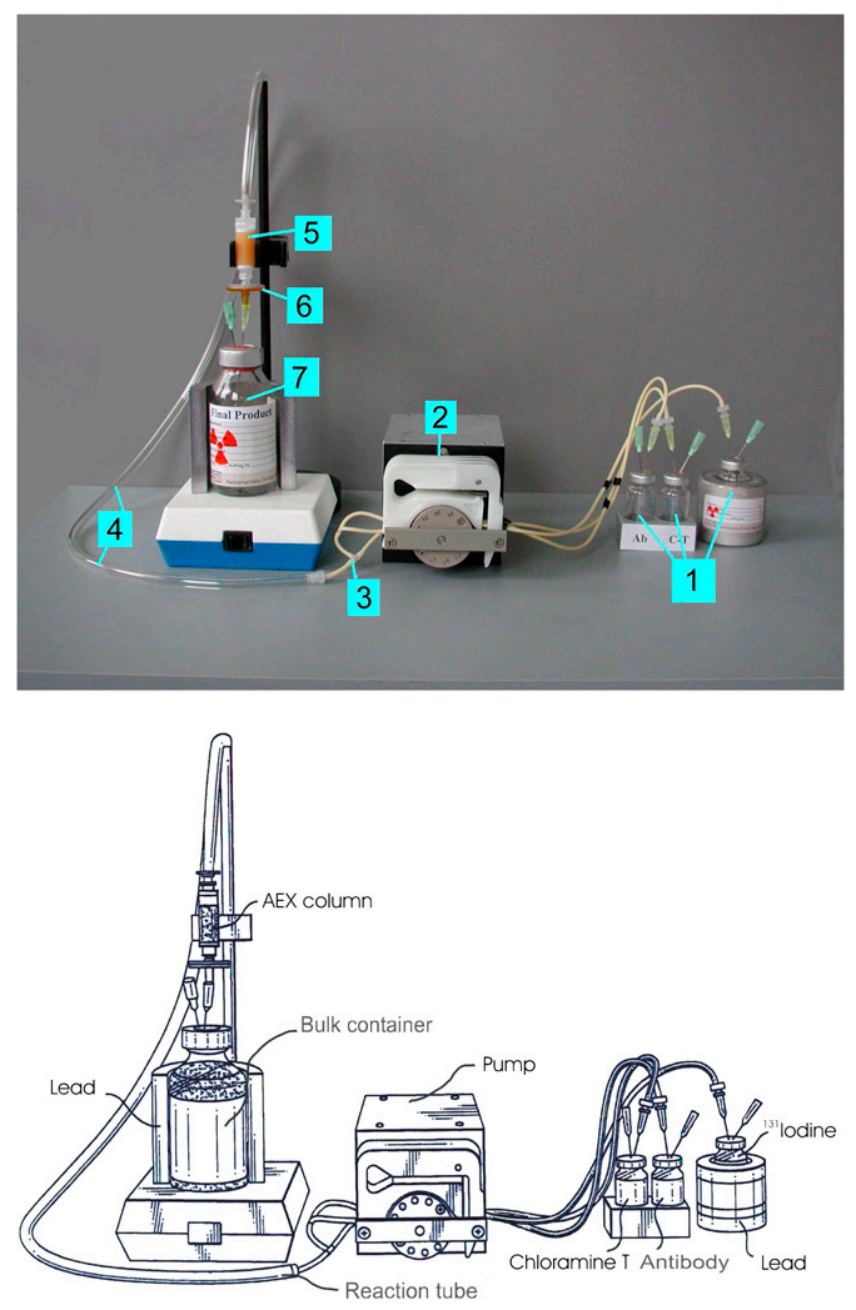

FIGURE 1. In-Line apparatus comprising following components: Reagent vials (1) containing antibody, chloramine$\mathrm{T}$, and ${ }^{131} \mathrm{I}$ (shielded in lead); 3-channel peristaltic pump (2) with tubing that channels reactants through a manifold (3) and into a reaction tube (4); in-line purification device (5), which can be either an ion-exchange column or a dialysis system; sterilization filter (6); and collection vial (7) containing all of the radioprotectants for the final product.

mixture passes through the manifold, it enters a single reaction tube. As the reagents flow through and continue to mix together in the reaction tube, the ${ }^{131} \mathrm{I}$ is bound to the antibody in the presence of chloramine-T. In one continuous flow, the reaction mixture is pumped directly onto an anionexchange (AEX) column for the removal of unincorporated (free) iodine, iodide, and chloramine-T, eliminating the need for sodium metabisulfite. Upon elution from the AEX column, the iodinated antibody is sterile-filtered and filled into vials already containing a radioprotectant formulation for administration to patients. The final product can then be frozen for shipment to the clinical site or for testing at a later date.

How we arrived at this process hinged on the initial challenge we had to meet: prepare a "patient dose" of approximately 8.33 $\mathrm{GBq}(225 \mathrm{mCi})$ of ${ }^{131} \mathrm{I}$ antibody on the day of manufacture to achieve $5.55 \mathrm{GBq}(150 \mathrm{mCi})$ by day 5 , and keep the volume to 
no more than 8-9 $\mathrm{mL}$. Before even considering an In-Line approach, we began by pushing the limits of radiolabeling with chloramine- $\mathrm{T}$ in a conventional reaction vessel.

\section{MATERIALS AND METHODS}

\section{In-Line Method of Labeling}

All labeling procedures, In-Line and batch, occurred in hot cells with activated charcoal ventilation at $22^{\circ} \pm 2^{\circ} \mathrm{C}$ (mean \pm SD). Chloramine-T labeling was conducted with 2 different antibodies using carrier-free ${ }^{131} \mathrm{I}$ delivered in sodium hydroxide (MDS Nordion) at approximately $25.9 \mathrm{GBq}$, approximately 111 $\mathrm{GBq}$, and $481 \mathrm{GBq}(\sim 700 \mathrm{mCi}, \sim 3 \mathrm{Ci}$, and $13 \mathrm{Ci}$, respectively). Neutralization of the ${ }^{131} \mathrm{I}$ in sodium hydroxide occurred using 0.1 $\mathrm{M}$ phosphate buffer ( $\mathrm{pH}$ 7.4) being brought to the final reactant volume. The time between dilution of the iodine and the start of the reaction was no more than $20 \mathrm{~min}$. Chloramine- $T$ was dissolved in sterile water and brought to the final reactant volume to deliver $1 \mathrm{mg}$ of chloramine- $\mathrm{T}$ for every $20,350 \mathrm{MBq}(550 \mathrm{mCi})$ of ${ }^{131} \mathrm{I}$. Antibody labeling occurred by drawing the protein, chloramine- $\mathrm{T}$, and ${ }^{131} \mathrm{I}$, using 3 separate silicone tubes (1.14-mm ID PharMed Ismaprene, catalog no. SC0310; Ismatec SA) and a 3-channel peristaltic pump (pump catalog no. IS3266, controller catalog no. IS3385; Ismatec SA), into a single tube (4.8-mm ID Tygon 3350 Silicone, catalog no. SC0582; Ismatec SA) in which the reaction was allowed to occur as the components flowed through the tube at flow rates between 1.3 and $2.3 \mathrm{~mL} / \mathrm{min}$. This In-Line reaction process allows for continuous flow right into an anionexchange column (Polymer SAX Rezorian Cartridge, catalog no. 2832-U; Supelco) for the removal of free iodide and chloramine-T before elution into a collection vial containing a final concentration of $0.65 \%(\mathrm{w} / \mathrm{v})$ sodium ascorbate as a radioprotectant (for research and development experiments, catalog no.A034; Sigma-Aldrich). The bulk is reformulated with human serum albumin (HSA) to a final concentration of $4.2 \%(\mathrm{v} / \mathrm{v})$ (Baxter Healthcare). Although research and development studies are discussed here, except for the anion-exchange column, all the components in contact with the reagents are sterile, pyrogenfree, and disposable, so no precleaning steps were necessary. The column was subjected to rinses with $1 \mathrm{M}$ sodium hydroxide for depyrogenation, $1 \mathrm{M}$ hydrochloric acid for activation, and a phosphate-buffered saline for neutralization before assembly with the other components. The system was assembled in a biologic safety cabinet and then transferred to a hot cell. Labeled antibodies were tested for binding potency, free iodide, yield, and percentage of intact antibody monomer, on the day of labeling and at $120 \mathrm{~h}$ by placing vials directly into storage at $-70^{\circ} \mathrm{C}$. Samples were thawed at $120 \mathrm{~h}$ by removal from the freezer and placement in a lead container at room temperature.

\section{Batch Method of Labeling}

The batch method of radiolabeling is characterized by a single reaction vessel with set reaction and purification times. More specifically, 3 individual syringes containing the carrier-free ${ }^{131} \mathrm{I}$ (MDS Nordion), the chloramine-T, and the antibody were combined through the charcoal-vented septum of a single enclosed borosilicate serum vial, which essentially functions as a conventional beaker (50 mL sterile, Allergy Laboratories). For data presented in Figure 2, each batch size was calculated to contain a final concentration of approximately $1 \mathrm{mg}$ of antibody per milliliter and $11.1 \mathrm{GBq}(300 \mathrm{mCi})$ of ${ }^{131} \mathrm{I}$. Phosphate buffer $(0.1 \mathrm{M})$ was used to dilute the ${ }^{131} \mathrm{I}(1: 10)$. The time between dilution of the iodine and the start of the reaction was no more than $20 \mathrm{~min}$. The chloramine- $\mathrm{T}$ for each batch was determined on the basis of the factor of $20,350 \mathrm{MBq}(550 \mathrm{mCi})$ of ${ }^{131} \mathrm{I}$ per milligram of chloramine-T. The reaction was made homogeneous through the spinning action of a presterilized stir bar and allowed to proceed for $10 \mathrm{~min}$. On completion, the reaction mixture was pumped through silicone tubing (Monostat, 75-300-015; Enviro Supply) to a freshly activated anion-exchange column (Polymer SAX Rezorian Cartridge, catalog no. 2832-U; Supelco) for the removal of chloramine-T and free iodide. The bulk product was filter-sterilized, assayed, and reformulated to contain $4.2 \%$ (v/v) HSA (Baxter Healthcare) and $0.65 \%(\mathrm{w} / \mathrm{v})$ sodium ascorbate (for research and development experiments, catalog no. A034; Sigma-Aldrich). The difference in volume was then brought up with saline (VWR International). The batch was resterilized and apportioned into aliquots to produce the final product, Cotara. The final vials were immediately placed in storage at $-70^{\circ} \mathrm{C}$. Assays were performed as above.

\section{Supplemental Materials}

Methods for determining binding potency, free iodide, and percentage of intact antibody monomer can be found in the supplemental materials (available online only at http://jnm.snmjournals.org).

\section{RESULTS AND DISCUSSION}

\section{Finding the Limits of Specific Activity in a Conventional Beaker for Our Antibody}

Increasing the specific activity allows for greater radiation doses to be delivered with a given amount of antibody, but at what specific activity does radiolysis affect antibody binding potency and the percentage of antibody that remains as an intact monomer (percentage monomer)? Equally important, greater specific activity requires greater concentrations of chloramine- $\mathrm{T}$, thus increasing oxidative damage. Activities were investigated at 0.37, 0.48, 0.63, $0.78,0.96$, and $1.11 \mathrm{GBq}(10,13,17,21,26$, and $30 \mathrm{mCi}$, respectively) of ${ }^{131} \mathrm{I}$ per milligram of antibody $(\mathrm{GBq} / \mathrm{mg}$ or $\mathrm{mCi} / \mathrm{mg})$. Antibodies were labeled with $300 \mathrm{mCi}(11.1$ GBq) of ${ }^{131} \mathrm{I}$ using $1.8 \mu \mathrm{g}$ of chloramine-T per millicurie of radiation (i.e., $540 \mu \mathrm{g}$ ) in a conventional batch procedure. All 6 reactions were brought to a final antibody concentration of $1 \mathrm{mg} / \mathrm{mL}$ in a radioprotectant cocktail of $0.65 \%$ ascorbate and $4.2 \%$ HSA in $0.9 \%$ saline. Samples were tested immediately on completion of labeling (day 0) and after storage at $-70^{\circ} \mathrm{C}$ for $120 \mathrm{~h}$ (day 5). Samples were further tested after thawing and storage at room temperature for $24 \mathrm{~h}$ (day $5+24 \mathrm{~h}$ ).

Besides testing for binding potency and percentage monomer, the spontaneous release of ${ }^{131} \mathrm{I}$ from its antibody-conjugated state was determined. It is reported as a percentage of the total ${ }^{131}$ I content in the final solution (percentage free iodide; Fig. 2A). Results indicated no differences in free iodide accumulation from day $0(<2 \%)$ until day $5+24 \mathrm{~h}(<5 \%)$ for the various specific activities. The binding potency of the labeled antibodies was more sensitive to the effects of increased specific activity (Fig. 2B). Binding potency was assessed by analyzing binding to the antigen target coated on microparticles. Radiolabeled 


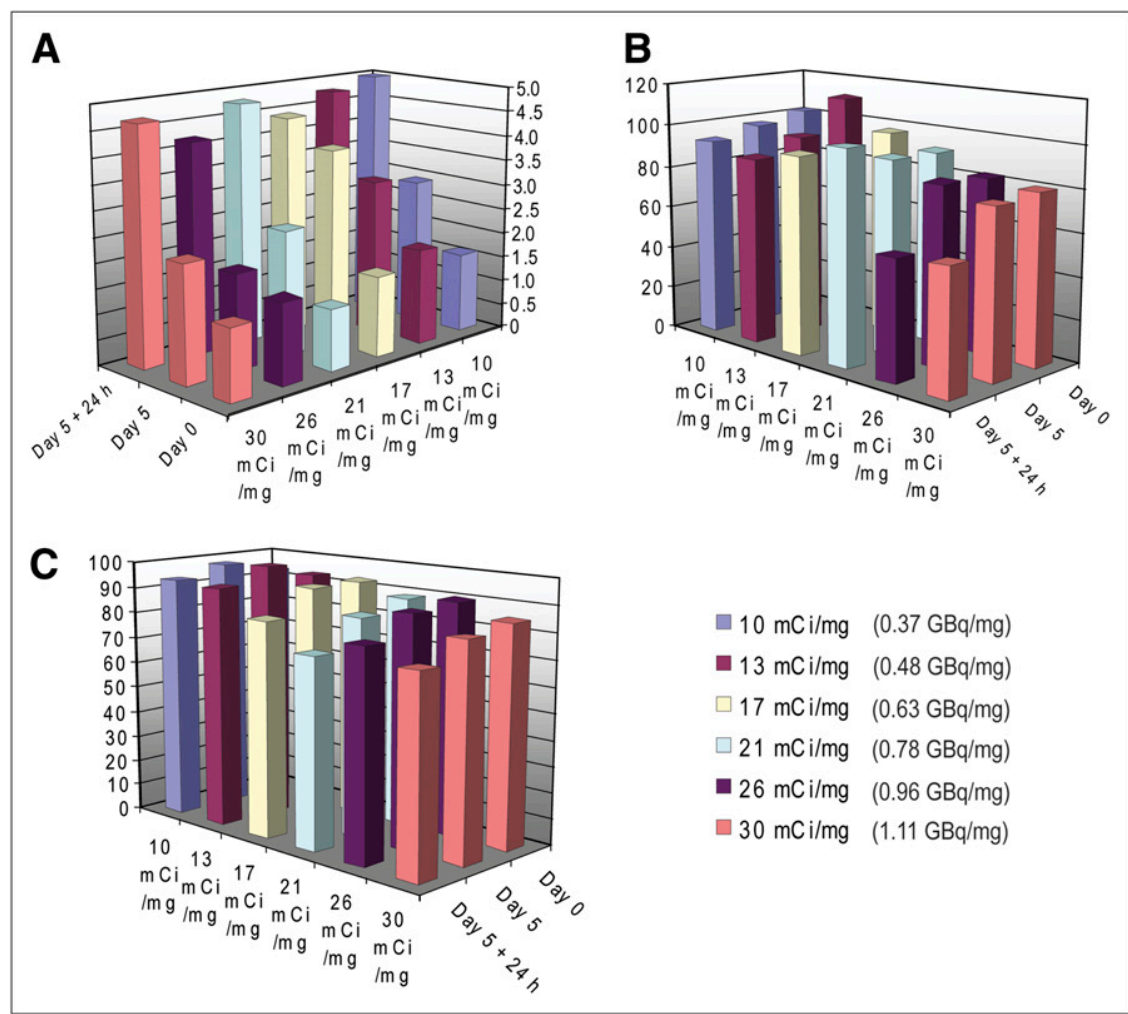

FIGURE 2. Increasing the specific activity of ${ }^{131}$ I label on the chTNT-1/B antibody using a conventional beaker for the reaction. Free iodide $(A)$, antibody binding potency $(\mathrm{B})$, and percentage monomer $(C)$ were investigated at $0.37,0.48,0.63,0.78,0.96$, and 1.11 $\mathrm{GBq} / \mathrm{mg}(10,13,17,21,26$, and 30 $\mathrm{mCi} / \mathrm{mg}$, respectively) on day 0 , day 5 , and day $5+24-\mathrm{h}$ room temperature. antibody was added to a solution containing the microparticles, and radioactive emissions were measured with a $\gamma$-counter. Nonfunctional antibody was washed off the microparticles before the particles were measured again in a $\gamma$-counter, this time for the functional radiolabeled antibodies. The binding potency was determined by dividing the value for the functional antibody with the value for total radiolabeled antibody. Results indicated greater than $85 \%$ binding potency throughout the course of the experiment for antibodies labeled up to $0.78 \mathrm{GBq} / \mathrm{mg}(21 \mathrm{mCi} / \mathrm{mg})$, with values significantly lower for antibodies labeled at 0.96 and $1.11 \mathrm{GBq} / \mathrm{mg}$ (26 and $30 \mathrm{mCi} / \mathrm{mg}$ ). Finally, percentage monomer was assessed chromatographically by size-exclusion fractionation of the labeled antibody into its monomeric, aggregated, and degraded forms, using a $\gamma$-detector to record the elution of each peak from the column. These results indicated that increasing the specific activity much beyond $0.63 \mathrm{GBq} / \mathrm{mg}(17 \mathrm{mCi} / \mathrm{mg})$ can adversely affect the percentage of intact monomeric antibody by day $5+24$ h (Fig. 2C). With less than $80 \%$ of the antibody monomeric, the remainder eluted as an aggregate, raising concerns of an immunogenic reaction in patients administered such a large amount of aggregating antibodies. These observations were consistent with those indicating that increased iodination levels lead to decreased solubility for a protein in aqueous solution (8).

\section{Finding the Limits of Radioactive Antibody \\ Concentration for a Maximum Patient Dose}

We first investigated the maximum specific activity that could be achieved with our antibody, to have it as radio- active as possible while still maintaining the binding potency and integrity of the antibody. Having determined that increasing the specific activity much beyond $0.63 \mathrm{GBq} /$ $\mathrm{mg}(17 \mathrm{mCi} / \mathrm{mg})$ would adversely affect the antibody, we next investigated increasing the antibody concentration in the final patient dose instead. A greater radiation dose can be delivered by supplying a greater amount of antibody to the tumor site using this strategy. Hence, rather than focus on millicuries per milligram, we turned our attention to increasing the millicuries per milliliter that can be delivered to the tumor site. Once again, a batch procedure with a conventional beaker was used for labeling. Three antibody lots were manufactured with $14.8-18.5 \mathrm{GBq}$ (400-500 $\mathrm{mCi}$ ) of ${ }^{131} \mathrm{I}$; each lot was then separated into three fractions after completion of the reaction, and the fractions were diluted to one of three concentration ranges before storage in frozen aliquots. The concentration ranges were chosen to determine whether a $3.33,4.44$, or $5.55 \mathrm{GBq}(90$, 120 , or $150 \mathrm{mCi}$, respectively) potent clinical dose could be achieved on day 5 using this strategy. The three concentration ranges were $0.666-0.74 \mathrm{GBq} / \mathrm{mL}(18-20 \mathrm{mCi} / \mathrm{mL}$; to simulate an $\sim 3.33 \mathrm{GBq}[\sim 90 \mathrm{mCi}]$ clinical dose at day 5), $0.814-0.888 \mathrm{GBq} / \mathrm{mL}(22-24 \mathrm{mCi} / \mathrm{mL}$; for an $\sim 4.44$ $\mathrm{GBq}[\sim 120 \mathrm{mCi}]$ clinical dose at day 5), and 0.999-1.073 $\mathrm{GBq} / \mathrm{mL}(27-29 \mathrm{mCi} / \mathrm{mL}$; for an $\sim 5.55 \mathrm{GBq}[\sim 150 \mathrm{mCi}]$ clinical dose at day 5-the maximum clinical dose to be administered). The specific activity was kept at $0.37 \mathrm{GBq} /$ $\mathrm{mg}(10 \mathrm{mCi} / \mathrm{mg})$, to avoid complications in the binding potency and percentage monomer data resulting from higher specific activities. Indeed, on the basis of our 
observations summarized in Figure 2, we considered the $0.37 \mathrm{GBq} / \mathrm{mg}(10 \mathrm{mCi} / \mathrm{mg})$ labeling of antibody as an optimal strategy for batch-labeling against which our InLine approach could be compared.

At all 3 concentrations, the results for free iodide were rather high (in nearly all cases on day $5+24 \mathrm{~h},>5 \%$ ). On average, antibodies that were still present as intact monomers remained greater than $80 \%$, and their binding potency remained greater than $70 \%$ in almost all instances, whether at day 0 , day 5 , or day $5+24 \mathrm{~h}$ (Fig. $3 \mathrm{~A})$. These results were promising because the concentration of activity as high as $0.999-1.073 \mathrm{GBq} / \mathrm{mL}$ (27-29 $\mathrm{mCi} / \mathrm{mL}$ ) indicated we had the ability to manufacture $8-\mathrm{mL}$ patient doses of $8.33 \mathrm{GBq}(225 \mathrm{mCi})$ Cotara that would decay to the target level of $5.55 \mathrm{GBq}(150 \mathrm{mCi})$ by day 5 and still maintain good overall stability. But limitations were clearly evident for the preparation of such high concentrations in a beaker. To illustrate, compare these results with the $10 \mathrm{mCi} / \mathrm{mg}(10 \mathrm{mCi} / \mathrm{mL})$ labeling at 11.1 GBq (300 $\mathrm{mCi})$ discussed earlier, where the free iodide was $5 \%$, the binding potency was $91.4 \%$, and the percentage monomer was $93.2 \%$. With optimization, no doubt some improvements would be seen for binding potency and percentage monomer using the increased radiolabeled antibody concentration approach; however, such a batch procedure would never lend itself to scale-up for multiple $(>3)$ patient doses. How could one get around the limitations of a batch-labeling process? For this reason, we created the In-Line radiolabeling approach as an alternative to labeling in a beaker or bucket.

What Is the Greatest Specific Activity and Antibody Concentration That Can Be Made Using the In-Line Process, and Is It Comparable to the Batch Process?

Because our earlier investigations with increasing specific activities had found an acceptable upper limit for specific activities at $0.63 \mathrm{GBq} / \mathrm{mg}(17 \mathrm{mCi} / \mathrm{mg})$, we decided to test the In-Line process by labeling antibodies at 0.63 and $0.48 \mathrm{GBq} / \mathrm{mg}$ (17 and $13 \mathrm{mCi} / \mathrm{mg}$ ). Cotara lots were manufactured by simultaneously pumping about 10 $\mathrm{mg} / \mathrm{mL}$ chTNT-1/B antibody, about $700 \mathrm{mCi}(25.9 \mathrm{GBq})$ of ${ }^{131} \mathrm{I}$, and approximately $1,300 \mu \mathrm{g}$ of chloramine-T (i.e., $\sim 1.8 \mu \mathrm{g}$ per $\mathrm{mCi}$ of radiation) from separate vials into a single reaction tube at a flow rate of $0.7 \mathrm{~mL} / \mathrm{min}$. The total volume for the reaction tube was $7 \mathrm{~mL}$; hence, the amount of time it took any fraction of the reaction mixture to travel the entire length of the tube was $10 \mathrm{~min}$. Put another way, it takes $10 \mathrm{~min}$ to replace the entire reaction tube volume. Upon reaching the end of the reaction tube, the reactants passed through an AEX column where the chloramine-T was removed, halting the reaction and negating the need for a reductant such as sodium metabisulfite. The time it took to label the entire lot of antibody depended on the volume of starting material. In these early experiments, each reactant was stored in a 6-mL volume of buffer in its respective vial for a total of $18 \mathrm{~mL}$ of reactants. With a 0.7
$\mathrm{mL} / \mathrm{min}$ flow rate, all $18 \mathrm{~mL}$ were processed within $30 \mathrm{~min}$ and the entire production lot filter sterilized as the product eluted from the AEX column and dripped into a radioprotectant cocktail for a final concentration of $0.65 \%$ ascorbate and $4.2 \%$ HSA in $0.9 \%$ saline.

The volumes were chosen to label the samples as close to $1.15 \mathrm{GBq} / \mathrm{mL}(31 \mathrm{mCi} / \mathrm{mL})$ as possible. At $1.15 \mathrm{GBq} / \mathrm{mL}$ (31 $\mathrm{mCi} / \mathrm{mL})$, the $0.48 \mathrm{GBq} / \mathrm{mg}(13 \mathrm{mCi} / \mathrm{mg})$ sample represents approximately $2.4 \mathrm{mg} / \mathrm{mL}$ of labeled antibody, whereas the $0.63 \mathrm{GBq} / \mathrm{mg}(17 \mathrm{mCi} / \mathrm{mg})$ is close to $1.8 \mathrm{mg}$ / $\mathrm{mL}$ of labeled antibody. By labeling to $1.15 \mathrm{GBq} / \mathrm{mL}(31$ $\mathrm{mCi} / \mathrm{mL}$ ), we could then divide each batch into three fractions after completion of the reaction and the fractions diluted to the three target concentrations of activity as before: $0.666-0.74 \mathrm{GBq} / \mathrm{mL}(18-20 \mathrm{mCi} / \mathrm{mL}), 0.814-0.888$ $\mathrm{GBq} / \mathrm{mL}(22-24 \mathrm{mCi} / \mathrm{mL})$, and $0.999-1.073 \mathrm{GBq} / \mathrm{mL}$ (27$29 \mathrm{mCi} / \mathrm{mL}$ ) before storage in frozen aliquots.

We investigated the same parameters-binding potency, percentage monomer, and free iodide - as before at day 0 , day 5, and day $5+24 \mathrm{~h}$ (Figs. 3B and 3C). Labeling of the antibody to $0.48 \mathrm{GBq} / \mathrm{mg}(13 \mathrm{mCi} / \mathrm{mg})$ was conducted in triplicate, and the analysis found that, on average, binding potency, percentage monomer, and free iodide were greater than $75 \%$ (aggregate mean of $83.8 \% \pm 12.7$ ), greater than $85 \%(90 \% \pm 2.6)$, and less than $3 \%(1.5 \% \pm 0.9)$, respectively, at days 0 and 5 . At day $5+24 \mathrm{~h}$ at room temperature, the binding potency was greater than $70 \%$ (aggregate mean of $75.0 \% \pm 6.6$ ), the percentage monomer greater than $80 \%(84.1 \% \pm 2.6)$, and the free iodide less than $5 \%(3.9 \% \pm 0.7)$ for all 3 concentrations of activity investigated (Fig. 3B).

Similarly, analysis of the $0.63 \mathrm{GBq} / \mathrm{mg}(17 \mathrm{mCi} / \mathrm{mg})$ data found the binding potency and percentage monomer to be greater than $75 \%$. The free iodide results were slightly greater than the $0.48 \mathrm{GBq} / \mathrm{mg}(13 \mathrm{mCi} / \mathrm{mg})$ values on the corresponding days, with free iodide often reaching $5 \%$ by day $5+24 \mathrm{~h}$ (Fig. 3C). Admittedly, labeling of the antibody to $0.63 \mathrm{GBq} / \mathrm{mg}(17 \mathrm{mCi} / \mathrm{mg})$ was done only in duplicate. The early percentage monomer data by day $5+24 \mathrm{~h}$ was not as good as the percentages obtained with the $0.48 \mathrm{GBq} / \mathrm{mg}(13 \mathrm{mCi} / \mathrm{mg})$ samples; indeed, $20 \%$ of the antibody was in an aggregated form when labeled to the target concentration of 0.999-1.073 GBq/mL (27-29 mCi/mL). Such a significant amount of aggregate could lead to immunogenicity problems with patients. These observations, combined with the moderately greater free iodide readings and the actual cost of running another $0.63 \mathrm{GBq} / \mathrm{mg}(17 \mathrm{mCi} / \mathrm{mg})$ labeling experiment, were factors in our decision to continue work only at a specific activity of $0.48 \mathrm{GBq} /$ $\mathrm{mg}(13 \mathrm{mCi} / \mathrm{mg})$. A comparison of the In-Line process (Figs. 3B and 3C) to the batch process (Fig. 3A), even at concentrations of $0.999-1.073 \mathrm{GBq} / \mathrm{mL}(27-29 \mathrm{mCi} /$ $\mathrm{mL}$ ), revealed comparable results for binding potency and percentage monomer. A statistical comparison is provided in the supplemental materials. 


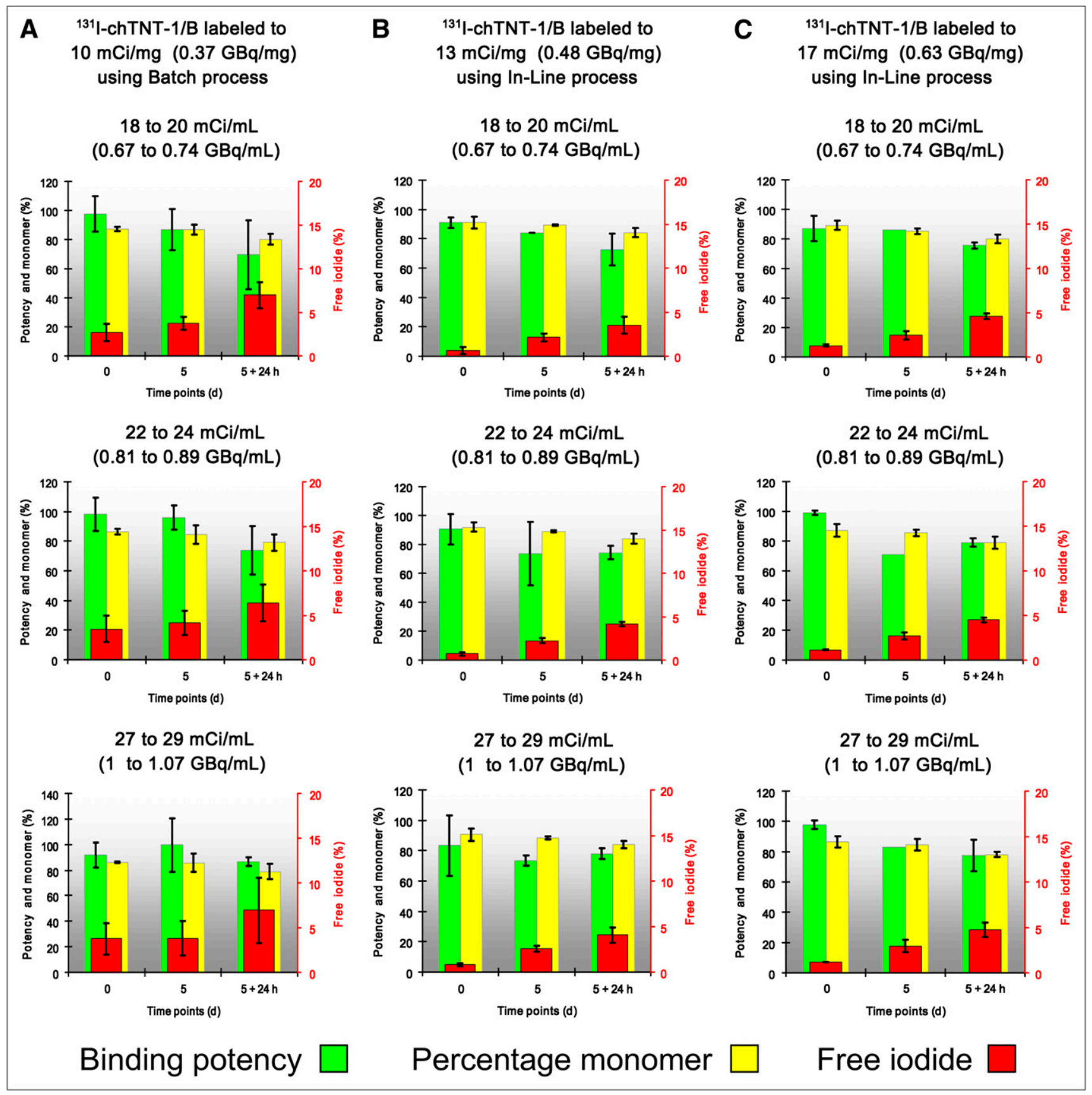

FIGURE 3. Increasing the concentration of ${ }^{131} \mathrm{I}$-chTNT-1/B antibody in the patient dose by labeling either in a conventional beaker (A) or in an In-Line apparatus (B and C). Binding potency and \% monomer are measured from the left $y$-axis, while free iodide is measured from the right $y$-axis. Note: Due to technical difficulties on day 5 of the $0.63 \mathrm{GBq} / \mathrm{mg}(17 \mathrm{mCi} / \mathrm{mg})$ labeling reactions, only one of two datasets for binding potency could be used, hence, the lack of error bars for that particular day 5 dataset in $(\mathrm{C})$.

\section{Demonstrating Scalability and Reproducibility of the In-Line Process}

We made the leap from $25.9 \mathrm{GBq}(700 \mathrm{mCi})$ to $111 \mathrm{GBq}$ (3 Ci) to simulate the production of approximately $10-12$ patient doses. Early work investigated the stability of labeling to approximately $0.48 \mathrm{GBq} / \mathrm{mg}(\sim 13 \mathrm{mCi} / \mathrm{mg})$ using $230 \mathrm{mg}$ of chTNT-1/B and nearly $3,000 \mathrm{mCi}(111$ $\mathrm{GBq}[3 \mathrm{Ci}]$ ) of ${ }^{131} \mathrm{I}$. This time, the total volume for the reaction tube was $17 \mathrm{~mL}$ and the flow rate was increased to $1.7 \mathrm{~mL} / \mathrm{min}$, so the actual time for any fraction of the reaction mixture to traverse the entire length of the reaction tube still remained $10 \mathrm{~min}$. Each reactant was diluted to its appropriate concentration in buffer and kept in its respective vial. The total volume for the reactants was about $30 \mathrm{~mL}$. With a 1.7 $\mathrm{mL} / \mathrm{min}$ flow rate, all $30 \mathrm{~mL}$ were processed within $20 \mathrm{~min}$ and the entire production lot filter-sterilized and dripped into 
the radioprotectant cocktail just as before. These 111-GBq (3-Ci) reactions were conducted in quadruplicate.

In a reaction with a $100 \%$ yield of ${ }^{131}$ I-conjugated antibodies, $83.3 \mathrm{GBq}(2,250 \mathrm{mCi})$ should be sufficient to prepare 10 patient doses exactly. Using a $\gamma$-counter, we were able to determine the amount of ${ }^{131} \mathrm{I}$ used at the start of the reaction. Once the reaction mixture had traversed the AEX column, unincorporated ${ }^{131}$ I should have been removed from the labeling process. The amount of ${ }^{131} \mathrm{I}$ conjugated to the antibodies was then determined, and the iodide percentage yield was estimated using a $\gamma$-counter. For the quadruplicate $111-\mathrm{GBq}$ (3-Ci) reactions, the percentage yield ranged from $88 \%$ to $92 \%$. These early samples were stored frozen in smaller aliquots (2.22$2.78 \mathrm{GBq}[60-75 \mathrm{mCi}]$ ) and were not investigated at day $5+24$-h room temperature. Free iodide did not exceed $5 \%$; on average, binding potency remained above $80 \%$ on day 0 and just below $80 \%$ on day 5 , and the percentage monomer was above $85 \%$ (Fig. 4A).

Until now, ${ }^{131} \mathrm{I}$-conjugated antibodies were apportioned into approximately 6-mL aliquots before freezing in most of the experiments described. Apportionment of enough materials from each labeling reaction for all of the time points and concentrations being investigated, while limiting human exposure to the radioactive samples and the available supply of chTNT-1/B antibodies, governed these considerations. However, once proof of principle had been demonstrated, we tested the stability of full $8.33-\mathrm{GBq}$ (225$\mathrm{mCi}$ ) doses within the preferred $8-\mathrm{mL}$ volume requested for the treatment of brain tumors. In a series of three 111-GBq (3-Ci) labeling reactions, chTNT-1/B was labeled to a specific activity of $0.48 \mathrm{GBq} / \mathrm{mg}(13 \mathrm{mCi} / \mathrm{mg})$ and a concentration of $0.999-1.073 \mathrm{GBq} / \mathrm{mL}(27-29 \mathrm{mCi} / \mathrm{mL})$. In the first of these reactions, the final product was apportioned into only 6-mL patient doses, corresponding to approximately $6.29 \mathrm{GBq}(\sim 170 \mathrm{mCi})$ of Cotara and frozen for analysis at the usual time points. Binding potency, percentage monomer, and free iodide were $78 \%, 95.6 \%$, and $2.5 \%$, respectively, at day 5 . At day $5+24 \mathrm{~h}$ at room temperature, the binding potency was $72 \%$, the percentage monomer $92.3 \%$, and the free iodide $4.5 \%$, indicating the feasibility of our strategy of making such large patient doses (Fig. 4B).

The next two reactions had the final product apportioned into 8-mL patient doses, corresponding to approximately $8.33 \mathrm{GBq}(225 \mathrm{mCi})$ of Cotara. For both of these 111-GBq (3-Ci) reactions, by day $5+24 \mathrm{~h}$, binding potency was $70 \%$, the percentage monomer greater than $80 \%$, and the free iodide remained less than 5\%. A graphical representation of the 6- and 8-mL data together illustrates the tight standard deviation and consistent results for all three parameters at all three time points (Fig. 4B). After demonstrating the stability of a 8.33-GBq (225-mCi) radiolabeled antibody frozen for up to $5 \mathrm{~d}$, thawed, and then kept at room temperature for a further $24 \mathrm{~h}$, we transferred the entire In-Line labeling process to a contract facility for Cotara manufacture and distribution by air within $5 \mathrm{~d}$ to clinical sites.
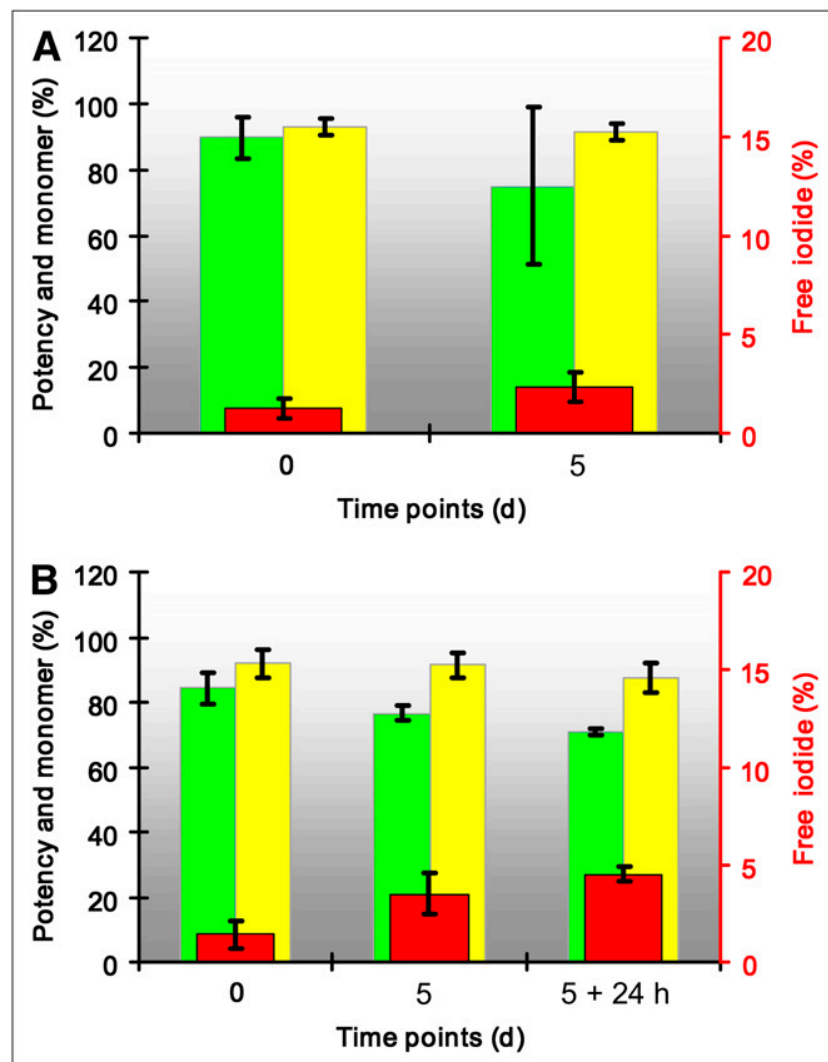

Binding potency $\square \quad$ Percentage monomer

Free iodide

FIGURE 4. Reproducible production of multiple patient doses at $111 \mathrm{GBq}(3 \mathrm{Ci})$. The In-Line system was used in the production of $10-12$ doses of ${ }^{131} \mathrm{I}$-conjugated chTNT-1/B. (A) Stability data for the early $111-\mathrm{GBq}(3-\mathrm{Ci})$ reaction runs $(n=4)$. (B) Stability data for the optimized 111-GBq (3-Ci) reaction runs $(n=3)$ that were subsequently apportioned into final patient doses of $6 \mathrm{~mL}(6.29 \mathrm{GBq}$ [170 $\mathrm{mCi}])$ or $8 \mathrm{~mL}$ (8.33 GBq [225 mCi]).

\section{The Versatility of In-Line Radiolabeling with Different Buffer Formulations}

Early in development, alternative formulations for the long-term storage of chTNT-1/B antibody were being investigated with the following 3 formulations as lead candidates: i) $88 \mathrm{mM}$ sucrose $-210 \mathrm{mM}$ alanine, $\mathrm{pH}$ 6.1; ii) $88 \mathrm{mM}$ sucrose $-210 \mathrm{mM}$ alanine in $100 \mathrm{mM}$ sodium phosphate, $\mathrm{pH} 6.1$; and iii) $250 \mathrm{mM}$ sucrose, $\mathrm{pH}$ 6.1. These formulations were being compared with the current phosphate buffer formulation for the antibody (10 mM sodium phosphate, $240 \mathrm{mM}$ sodium chloride, $\mathrm{pH}$ 7.6). Although freezing and thawing in phosphate buffer may lead to antibody denaturation, sucrose reduces this risk and still provides the correct tonicity for patient administration. To assess any complications to the In-Line process due to viscosity or formulation, scaled-down reactions were run with $15 \mathrm{mg}$ of chTNT-1/B and nearly $8.14 \mathrm{GBq}(220 \mathrm{mCi})$ 
of ${ }^{131} \mathrm{I}$ in the 4 formulations. Once again, the actual time for any fraction of the reaction mixture to traverse the entire length of the reaction tube was kept to $10 \mathrm{~min}$. Because the reaction tube for these experiments had a $10-\mathrm{mL}$ volume (553-mm length; 4.8-mm inner diameter), the flow rate was adjusted to $1 \mathrm{~mL} / \mathrm{min}$. As before, for each formulation tested, the final product was eluted from the AEX column and dripped into a radioprotectant cocktail for a final concentration of $0.65 \%$ ascorbate and $4.2 \%$ HSA in $0.9 \%$ saline before storage in frozen aliquots. Samples from each formulation were then tested at days 0,3 , 5 , and 7 .

A graphical summary of results shows binding potency, percentage monomer, and free iodide to be comparable for reactions run with the chTNT-1/B antibody stored either in the phosphate formulation or in $88 \mathrm{mM}$ sucrose $-210 \mathrm{mM}$ alanine (Figs. 5A and 5B). The same could be said for the antibody stored in $250 \mathrm{mM}$ sucrose; however, these sucrose-based formulations also provided the opportunity to investigate the percentage yield of In-Line-labeled antibody at varying viscosities. Good yields were obtained for a buffer with sucrose at $88 \mathrm{mM}$ (i.e., $3 \% \mathrm{w} / \mathrm{v}$ ), but an increase to $250 \mathrm{mM}$ sucrose (i.e., $8.5 \% \mathrm{w} / \mathrm{v}$ ) resulted in a poor yield (Fig. 5C). However, a good yield does not ensure a potent antibody. This is best illustrated by the $75 \%$ yield obtained with the antibody formulated in $88 \mathrm{mM}$ sucrose $-210 \mathrm{mM}$ alanine in $100 \mathrm{mM}$ sodium phosphate, which resulted in a precipitous drop in binding potency over the course of the $7 \mathrm{~d}$ after labeling (Fig. 5D).

\section{Getting to Commercial Scale}

Given the limitless amounts of protein that can theoretically be labeled with the continuous-flow procedure, we set out to label nearly a gram of a totally different antibody that was made available to us with $481 \mathrm{GBq}(13$ Ci) of ${ }^{131}$ I. The antibody, known as Lym-1, was labeled to a specific activity of about $0.48 \mathrm{GBq} / \mathrm{mg}(13 \mathrm{mCi} / \mathrm{mg})$ using $30 \mathrm{mg}$ of chloramine-T. As was the case for smallerscale reactions, the reactants were kept in their respective vials until mixing occurred in the reaction tube. The total volume for the reaction tube was $23 \mathrm{~mL}$, and the flow rate was increased to $2.3 \mathrm{~mL} / \mathrm{min}$; hence, the total time spent traversing the length of the tube was still kept to $10 \mathrm{~min}$ for any portion of the reaction. The total volume for the reactants was about $70 \mathrm{~mL}$. With a $2.3 \mathrm{~mL} / \mathrm{min}$ flow rate, all $70 \mathrm{~mL}$ were processed in $30 \mathrm{~min}$. Because of the cost of the materials and the special safety requirements necessary for such a high activity, this was a one-time experiment. The labeled antibody was apportioned into $10.4-\mathrm{GBq}(280-\mathrm{mCi})$ "patient doses" to achieve a 7.96 $\mathrm{GBq}(215-\mathrm{mCi})$ dose for testing at $72 \mathrm{~h}$ and a 6.66-GBq $(180-\mathrm{mCi})$ dose at $120 \mathrm{~h}$.

The percentage yield for the final product was $95.6 \%$. Patient doses were stored at $-70^{\circ} \mathrm{C}$ until testing at 72 and $120 \mathrm{~h}$ (i.e., 3 and $5 \mathrm{~d}$ ). Testing was also conducted on the sample thawed at $72 \mathrm{~h}$ and left at room temperature for up to $48 \mathrm{~h}$ The results for binding potency, percentage monomer, and free iodide are summarized in Table 1. They indicate that such a large scale of production can produce
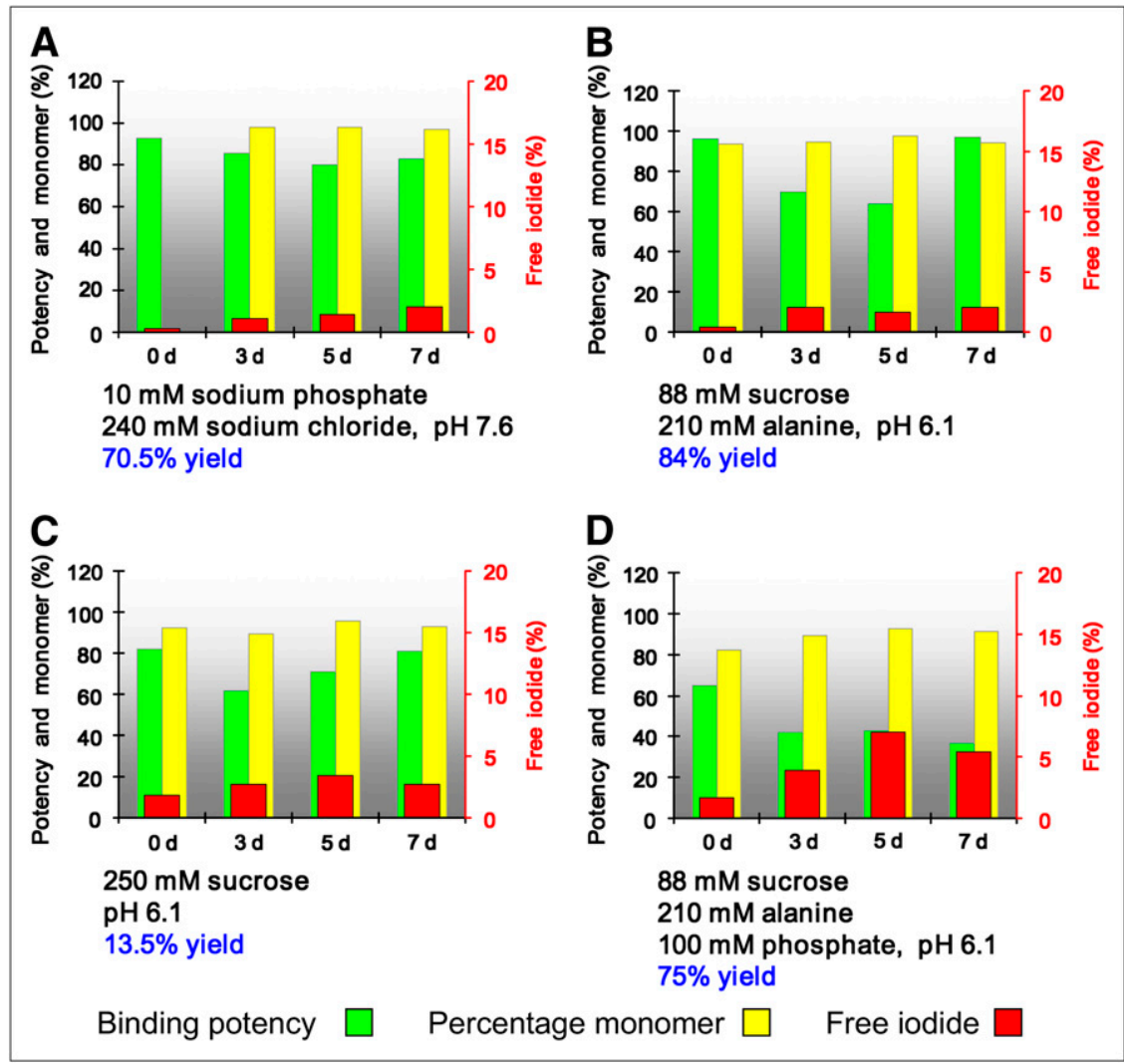

FIGURE 5. System versatility with buffers of varying viscosity. Ability to label chTNT-1/B stored in different formulations was tested with the In-Line apparatus. Sucrose-based formulations (B-D) were compared with the current phosphate buffer formulation for the antibody (A). 


\begin{tabular}{|c|c|c|c|c|c|c|}
\hline Parameter & Day 0 & Day 3 & Day $3+6 h^{*}$ & Day $3+24 \mathrm{~h}^{*}$ & Day $3+48 h^{*}$ & Day 5 \\
\hline Percentage potency & t & t & 87 & 91 & 79 & 88 \\
\hline Percentage monomer & $>95$ & 96.1 & 95.6 & $>95$ & 96.9 & 96.3 \\
\hline Free iodine & 0.7 & 3.0 & 4.1 & 5.6 & 7.4 & 2.8 \\
\hline $\begin{array}{l}{ }^{*} \text { Samples thawed on } \\
{ }^{\dagger} \text { Results had to be } \mathrm{d} \\
\text { Reactant 1: } 487.3 \mathrm{GE} \\
\mathrm{mL} \text { of } \mathrm{H}_{2} \mathrm{O} \text {; reactant } 3: 1 \\
\text { total reaction time: } 30 \mathrm{~m}\end{array}$ & $\begin{array}{l}\text { were al } \\
\text { d, becau } \\
170 \mathrm{mCi} \\
\mathrm{g} \text { of } \mathrm{Lym} \\
\text { Id: } 466.8\end{array}$ & $\begin{array}{l}\text { ted after } \\
\text { ear regre } \\
{\left[{ }^{131} \mathrm{l}\right] \mathrm{l} \text { in }} \\
50 \mathrm{~mL} \text { of } \\
(12,616\end{array}$ & $\begin{array}{l}\text { ge at room tem } \\
\text { analysis was } n \\
\text { of } 0.1 \mathrm{M} \text { phosp } \\
\text { hate buffer; rea } \\
\rightarrow 95.6 \% \text {. }\end{array}$ & $\begin{array}{l}\text { ure for } 6,24 \text {, and } \\
\text { sible. } \\
\text { buffer, } \mathrm{pH} 7.4 \text {; re } \\
\text { tube volume: } 23-r\end{array}$ & $\begin{array}{l}\text { 2: } 30 \mathrm{mg} \text { of chlo } \\
\text { con tube; flow ra }\end{array}$ & $\begin{array}{l}\text { e-T in } 10 \\
\mathrm{~mL} / \mathrm{min} \text {; }\end{array}$ \\
\hline
\end{tabular}

drugs that on day 5 are highly potent (88\%), not aggregating ( $>95 \%$ monomer), and low on free iodide $(2.8 \%)$.

\section{CONCLUSION: SIMPLE YET VERSATILE}

For comparison, a recent high-dose labeling strategy uses the coating of IODO-GEN directly onto the antibody surface by adding it, in acetonitrile, to the reaction in a vial (9). Subsequent deactivation of the IODO-GEN with ascorbic acid controls the reaction; however, the presence of acetonitrile raises safety concerns for commercial pharmaceutical production. At their highest dose, $5 \mathrm{mg}$ of antibody were labeled with $4.3 \mathrm{GBq}(116 \mathrm{mCi})$ of ${ }^{131} \mathrm{I}$, and the final product $(0.37 \mathrm{GBq} / \mathrm{mL}, 0.5 \mathrm{mg}$ antibody $/ \mathrm{mL})$ was stored in a radioprotectant for $24 \mathrm{~h}$ at room temperature, resulting in a binding potency of $62 \%$ (9). With our antibody labelings at 111 and $481 \mathrm{GBq}$, the final product remained potent and structurally intact despite routine storage at greater than $1 \mathrm{GBq} / \mathrm{mL}$ for $5 \mathrm{~d}$ at $-70^{\circ} \mathrm{C}$ and then $24 \mathrm{~h}$ at ambient temperature.

While we believe these results are groundbreaking, we believe the process can be further optimized. By simply adjusting the inner diameter of the tubing and the flow rate, one can exert tremendous control over the rate of a reaction process. Indeed, using different tubing sizes for each reactant removes the need to dilute all reactants to a single volume. Reactants of different concentrations and volumes can all be mixed into the same reaction tubing as long as the tubing leading from the reagent vials into the manifold is adjusted for the amount of reagent expected to enter the reaction tube in a given amount of time. Preliminary data have already been acquired from reaction runs that use different size tubing for the reactants (data not shown).

These results help affirm our belief that using a continuousflow method of labeling molecules in silicone tubing as a reaction vessel helps reduce damage from radiolysis by dissipating the radiation levels encountered by an antibody. Furthermore, exposure to chloramine- $\mathrm{T}$ is also limited and the need for a reductant eliminated. But, most important, such an In-Line radiolabeling process allows for significant manufacturing scale-up for multiple patient doses while bringing down the overall production costs for the drug product. Requiring no sophisticated instrumentation, the process is versatile enough to be implemented in any radiation facility that has a hot cell with activated charcoal ventilation. In fact, the In-Line process is already being used for the manufacture of Cotara, in both the United States and India, as part of ongoing clinical trials to treat glioblastoma multiforme. In theory, the amount of protein that can be labeled is limitless as long as appropriate adjustments are made to the dimensions of the tubing.

We envision a system that is versatile enough to be applied beyond radiolabeling to the conjugation of nonisotopic materials to other molecules. For instance, oxidizing agents such as chloramine-T can be replaced with bifunctional cross-linking or chelating agents, and the ${ }^{131}$ I can be replaced with a myriad of other tags, including gadolinium, fluorochromes, quantum dots, and other proteins.

\section{ACKNOWLEDGMENTS}

We thank Dr. Andries Zijlstra for a critical reading of the manuscript and Dr. Robert Newcomb of the UCI Center for Statistical Consulting for statistical analysis.

\section{REFERENCES}

1. Chen S, Yu L, Jiang C, et al. Pivotal study of iodine-131-labeled chimeric tumor necrosis treatment radioimmunotherapy in patients with advanced lung cancer. J Clin Oncol. 2005;23:1538-1547.

2. Zelenetz AD. A clinical and scientific overview of tositumomab and iodine I 131 tositumomab. Semin Oncol. 2003;30(2, suppl 4):22-30.

3. Li CH. Iodination of tyrosine groups in serum albumin and pepsin. J Am Chem Soc. 1945;67:1065-1069.

4. Pressman D, Keighley G. The zone of activity of antibodies as determined by the use of radioactive tracers: the zone of activity of nephritoxic antikidney serum. J Immunol. 1948;59:141-146.

5. Adam MJ, Wilbur DS. Radiohalogens for imaging and therapy. Chem Soc Rev. 2005;34:153-163.

6. U.S. Nuclear Regulatory Commission. Release of Patients Administered Radioactive Materials. US Nuclear Regulatory Commission Regulatory Guide 8.39. Washington, DC: U.S. Nuclear Regulatory Commission; 1997.

7. Patel S, Shapiro W, Laske D, et al. Safety and feasibility of convection-enhanced delivery of Cotara for the treatment of malignant glioma: initial experience in 51 patients. Neurosurgery. 2005;56:1243-1253.

8. Hermanson GT. Bioconjugate Techniques. San Diego, CA: Academic Press; 1996.

9. Visser GW, Klok RP, Gebbinck JWK, ter Linden T, van Dongen GA, Molthoff CF. Optimal quality ${ }^{131} \mathrm{I}$-monoclonal antibodies on high-dose labeling in a large reaction volume and temporarily coating the antibody with IODO-GEN. J Nucl Med. 2001;42:509-519. 